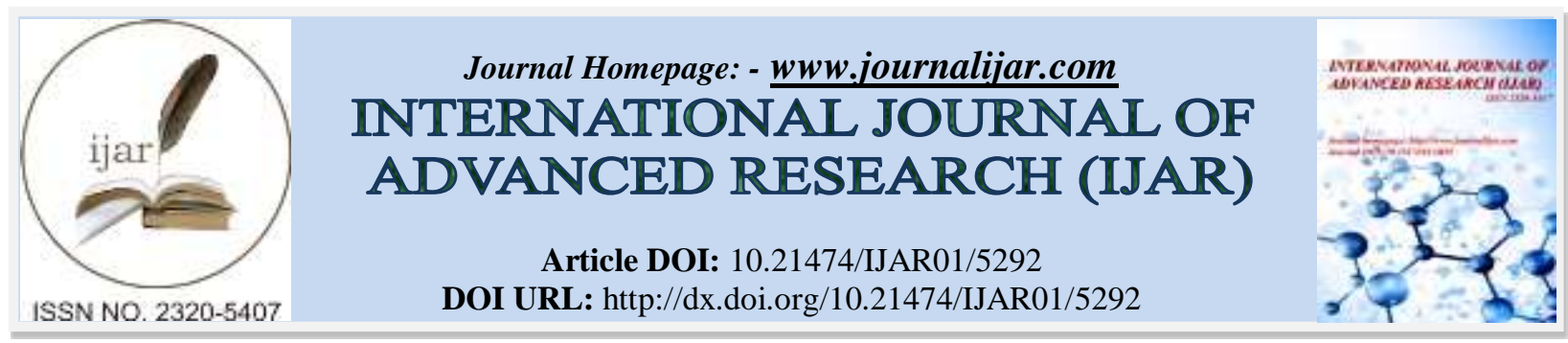

RESEARCH ARTICLE

\title{
ASSESSMENT OF TOTAL PROTEIN, ALBUMIN, TRIGLYCERIDE AND TOTAL CHOLESTEROL AMONG SUDANESE PATIENTS WITH TUBERCULOSIS IN KHARTOUM STATE.
}

\begin{abstract}
Shima Ahmed Hussein Ali ${ }^{1}$ and Nuha Eljaili Abubaker ${ }^{2}$.
1. Al- Neelain University. Faculty of Medical Laboratory Sciences, Department of Clinical chemistry.

2. Sudan University of science and Technology,. Faculty of Medical Laboratory Sciences, Head Department Of Clinical chemistry.
\end{abstract}

\section{Manuscript Info}

Manuscript History

Received: 01 July 2017

Final Accepted: 03 August 2017

Published: September 2017

Key words:-

Total proteins, albumin, cholesterol, triglyceride and tuberculosis.

\section{Abstract}

Background: Tuberculosis or TB is a common and often deadly infectious disease caused by various strains of mycobacterium; usually Mycobacterium tuberculosis in humans.

Objectives: The aim of this study to evaluate the level of serum albumin, total proteins, cholesterol and triglyceride among Sudanese patients with Tuberculosis.

Methods: Cross sectional study was conducted during the period from March to May 2017, eighty samples from known patients with TB as case and forty samples from healthy person as control. The level of total proteins, albumin, cholesterol and TG was measured using Mindray BS-120; Data were collected using structural questionnaire. Data analysis was carried out by means of statistical package for social science (SPSS version 16).

Results: The mean levels of total proteins, albumin, cholesterol and triglyceride showed significant decreased in tuberculosis patients when compared with healthy individuals with $(\mathrm{P}$. value $=0.000,0.000,0.015$ and 0.000) respectively. There were insignificant different in the levels of total proteins, albumin, cholesterol and TG in tuberculosis patients according to gender. The result of this study showed that, there was significantly decreased in BMI in patients with tuberculoses compared to control group ( $\mathrm{p}$ - value $=0.000$ ). There were negative correlation between the levels of serum total proteins, albumin, total cholesterol, triglyceride and ages. $(\mathrm{r}=-0.356, \mathrm{p}$, value $=0.001) \quad(\mathrm{r}=-0.273, \mathrm{p}$, value $=0.014)(\mathrm{r}=-0.296, \mathrm{p}$, value $=0.008)(\mathrm{r}=-0.223, \mathrm{p}$, value $=0.047)$ respectively.

Conclusion: The levels of total proteins, albumin, cholesterol and triglyceride were significantly decreased in Tuberculosis patients.

Copy Right, IJAR, 2017,. All rights reserved.

\section{Introduction:-}

Tuberculosis or TB is a common and often deadly infectious disease caused by various strains of mycobacterium; usually Mycobacterium tuberculosis in humans. ${ }^{(1)}$ Tuberculosis usually attacks to the lungs but can also affect other parts of the body. It spread through the air when people who have the disease cough, sneeze, or spit. ${ }^{(2)}$ Worldwide,

Corresponding Author:- Shima Ahmed Hussein Ali. chemistry. 
TB is responsible for more than 1.5 million deaths every year. ${ }^{(3)}$ Although treatments are available, tuberculosis still remains a leading cause of death worldwide. ${ }^{(4)}$

The revised estimate in the latest 2014 World Health Organization global tuberculosis report states that almost half a million more cases of tuberculosis occurred worldwide compared with the 2013 estimate; moreover, 1.5 million people died (up from 1.3 million in 2012) out of the estimated nine million people who developed tuberculosis in 2013. Specifically, tuberculosis infection may cause malnutrition through increased metabolic demands and decreased nutrient intake, while nutritional deficiencies may worsen the disease or delay recovery by inhibiting important immune functions. ${ }^{(5)}$

People with tuberculosis are often malnourished, and malnourished people are also at a higher risk of developing tuberculosis since their immune systems are weakened.

Tuberculosis has been associated with malnutrition. Malnutrition appears to increase the risk of developing tuberculosis, particularly in animal models. ${ }^{(6)}$ However; cause and effect are difficult to distinguish because tuberculosis disease causes weight loss.

Albumin has been reported low in pulmonary tuberculosis ${ }^{(7)}$. Increased serum albumin after one week of drug therapy has been reported by Vissers et al. ${ }^{(8)}$ Yamagishi et al 1999 and Yamanaka et al 2001 also reported that serum cholesterol and triglyceride was significantly lower in tuberculosis patients and got worse in homeless patients. ${ }^{(9)}$

${ }^{(10)}$ Weight loss and nutritional depletion are often seen in patients with tuberculosis at the time of tuberculosis diagnosis. ${ }^{(11)}$ Body mass index (BMI) is a more accurate marker of nutritional status than weight because it also takes height into account. ${ }^{(12)}$

\section{Materials and methods:-}

Study Population: The study was carried out at College of Medical laboratory Sciences, and the subjects were recruited from Aboangha Hospital in Omdurman, Khartoum(Sudan) from March to May 2017.

A total of 120 individual were enrolled in this study; divided into two groups, Eighty tuberculosis patients aged from 20-80 years as case, and forty healthy individuals as control. The study was approved by hospital's ethics committee. Informed consent was obtained from patients before blood sampling.

Inclusion criteria: include all patients diagnosed with TB.

Exclusion criteria: exclude any patient with (liver disease, renal disease and malignant tumor)

\section{Blood sample and Analysis:-}

About $2 \mathrm{ml}$ of venous blood was collected from the antecubital vein by taking aseptic precautions. Care was taken to prevent venous stasis during the sample collection. The blood was allowed to clot and the serum was separated by centrifugation. The estimation of the parameters was carried out within 4-6 hrs. The samples were analyzed for serum levels of total proteins, albumin, cholesterol and triglyceride by using Mindray BS-120. ${ }^{(13)}$ The internal control sera of two different levels were used to calibrate the instruments.

Data was analyzed using SPSS computer program, the mean and standard deviation were obtained and the independent 't.test' used for comparison ( $\mathrm{p}$ value of $\leq 0.05$ ) was considered significant.

\section{Results:-}

eighty samples from known patients with Tuberculosis as case and forty samples from healthy person as control were enrolled in the study. As shown in (Table 1), the mean level of total proteins, albumin, cholesterol, and triglyceride showed significant decreased in patients with tuberculosis when compared to healthy individuals with (P. value $=0.000,0.000,0.015$ and 0.000$)$ respectively. 
Table (1):- mean comparison of serum total proteins, albumin, total cholesterol and triglyceride between patients and control.

\begin{tabular}{|l|l|l|l|}
\hline Variables & $\begin{array}{l}\text { Case }(\text { Mean } \pm \mathrm{SD}) \\
\mathrm{n}=80\end{array}$ & $\begin{array}{l}\text { Control }(\text { Mean } \pm \text { SD }) \\
\mathrm{n}=40\end{array}$ & P-value \\
\hline Total proteins $(\mathrm{g} / \mathrm{dI})$ & $6.39 \pm 0.78$ & $7.38 \pm 0.57$ & 0.000 \\
\hline ALB $(\mathrm{g} / \mathrm{dI})$ & $3.22 \pm 0.58$ & $4.18 \pm 0.44$ & 0.000 \\
\hline Cholesterol $(\mathrm{mg} / \mathrm{dI})$ & $113.81 \pm 29.22$ & $128.45 \pm 33.57$ & 0.015 \\
\hline Triglycerides $(\mathrm{mg} / \mathrm{dl})$ & $77.76 \pm 22.02$ & $109.02 \pm 29.13$ & 0.000 \\
\hline
\end{tabular}

Results expressed as Mean \pm SD and significant differences considered as $\mathrm{p}$-value $\leq 0.05$.

Table (2):- mean comparison of serum total proteins, albumin, total cholesterol and triglyceride in tuberculosis patients according to gender.

\begin{tabular}{|l|l|l|l|}
\hline Variables & Male $($ Mean $\pm \mathrm{SD})$ & Female $($ Mean \pm SD $)$ & P-value \\
\hline Total proteins $(\mathrm{g} / \mathrm{dI})$ & $6.35 \pm 0.73$ & $6.42 \pm 0.85$ & 0.708 \\
\hline ALB $(\mathrm{g} / \mathrm{dI})$ & $3.18 \pm 0.56$ & $3.26 \pm 0.63$ & 0.550 \\
\hline Cholesterol $(\mathrm{mg} / \mathrm{dI})$ & $116.53 \pm 28.73$ & $109.51 \pm 29.93$ & 0.025 \\
\hline Triglycerides $(\mathrm{mg} / \mathrm{dl})$ & $80.26 \pm 23.77$ & $73.80 \pm 18.62$ & 0.089 \\
\hline
\end{tabular}

Results expressed as Mean \pm SD and significant differences considered as $p$-value $\leq 0.05$.

Table (3):- Mean of BMI among tuberculosis patients

\begin{tabular}{|l|l|l|l|}
\hline Variable & $\begin{array}{c}\text { Case } \\
\text { Mean } \pm \text { SD }\end{array}$ & $\begin{array}{c}\text { Control } \\
\text { Mean } \pm \text { SD }\end{array}$ & P-value \\
\hline BMI & $16.68 \pm 0.17$ & $21.54 \pm 1,72$ & 0.04 \\
\hline
\end{tabular}

The result showed that, $61 \%$ of patients were male and $39 \%$ were female as in fig (1) .There were negative correlation between the levels of serum total proteins, albumin, total cholesterol, triglyceride and ages. $(\mathrm{r}=-0.356$, $\mathrm{p}$, value $=0.001)(\mathrm{r}=-0.273, \mathrm{p}$, value $=0.014)(\mathrm{r}=-0.296, \mathrm{p}$, value $=0.008)(\mathrm{r}=-0.223, \mathrm{p}$, value $=0.047)$ respectively as in fig $(2 \& 3 \& 4 \& 5)$.

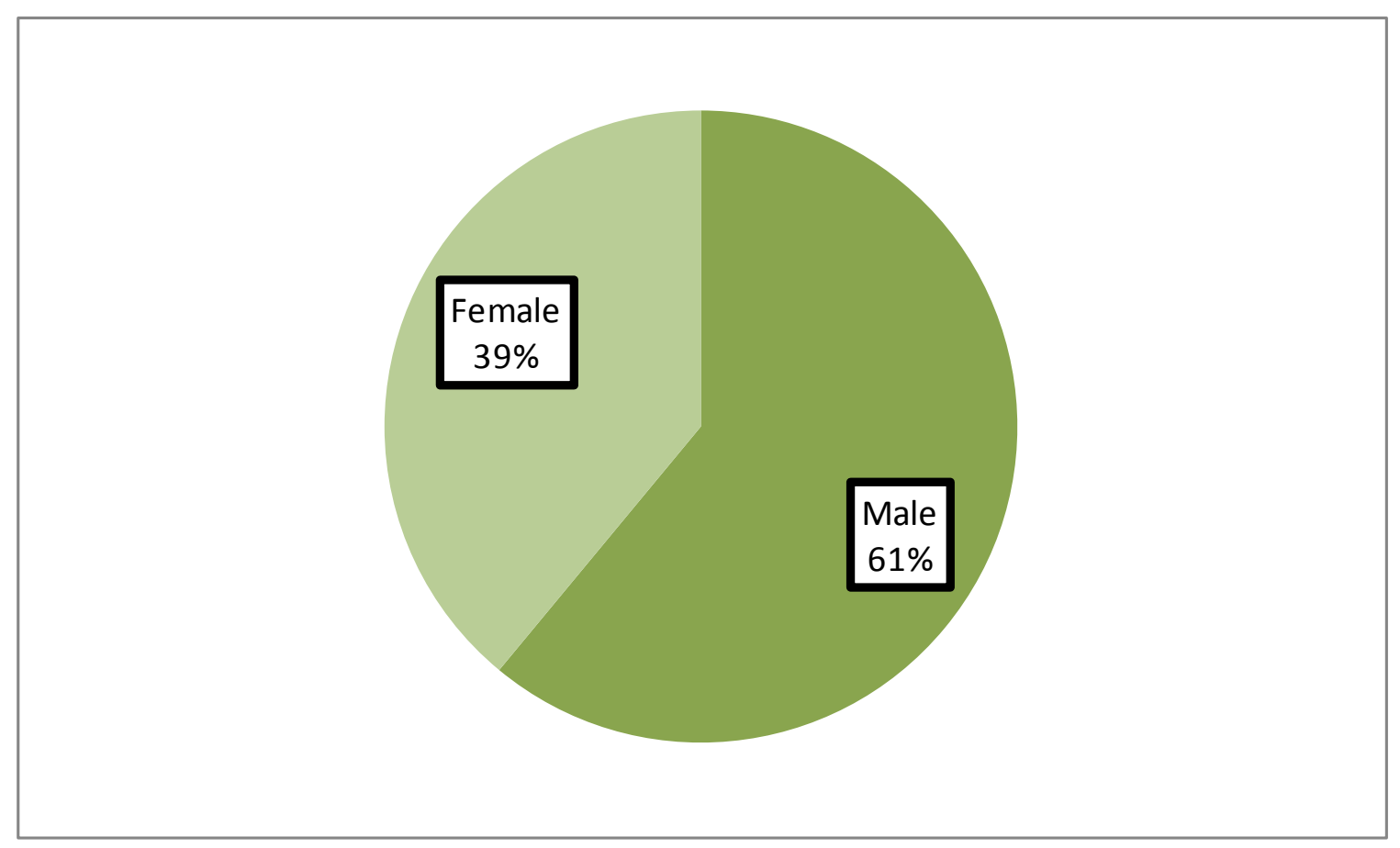

Figure (1):- percentage of gender distribution among study group . 


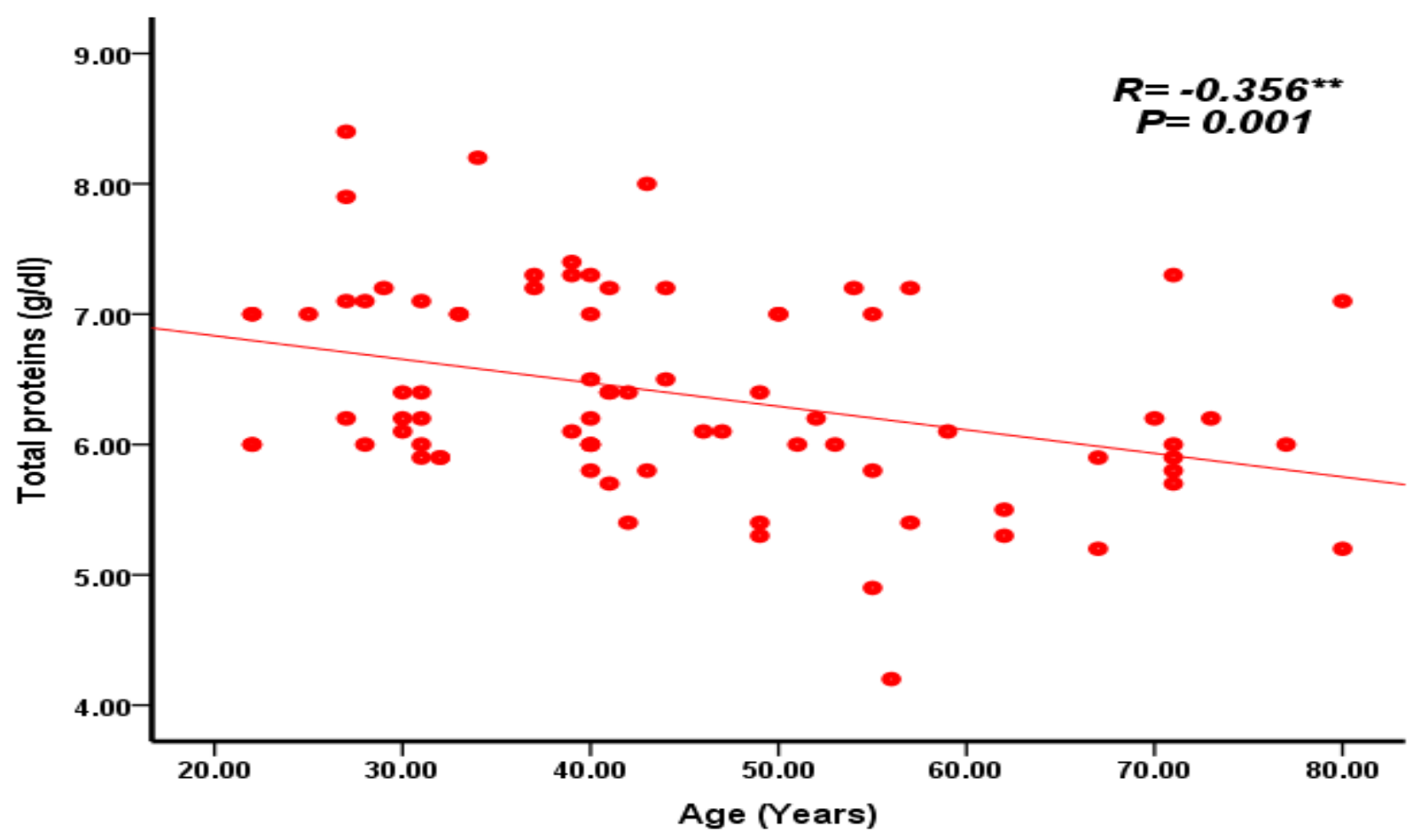

Figure (2):- correlation between total proteins level and age group in tuberculosis patients.

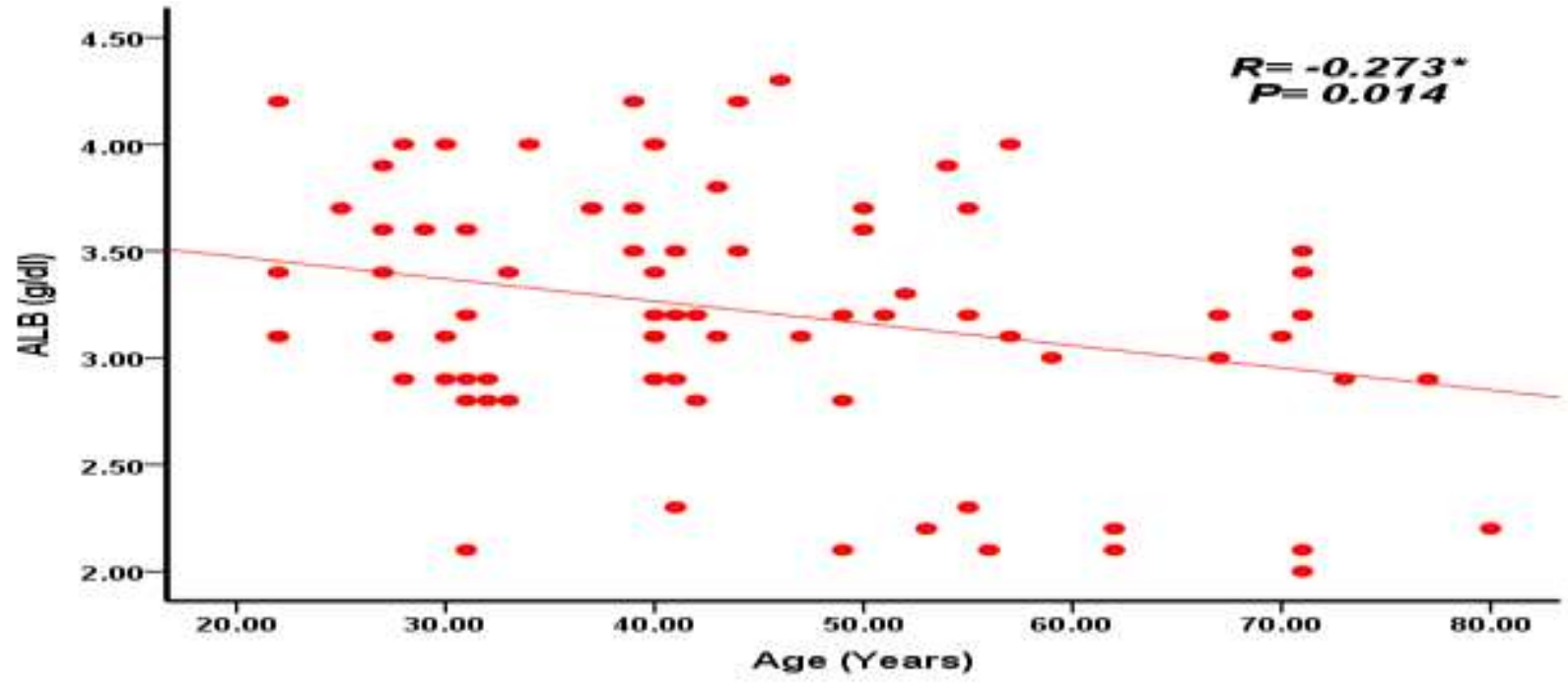

Figure (3):- correlation between albumin level and age group in tuberculosis patients: 


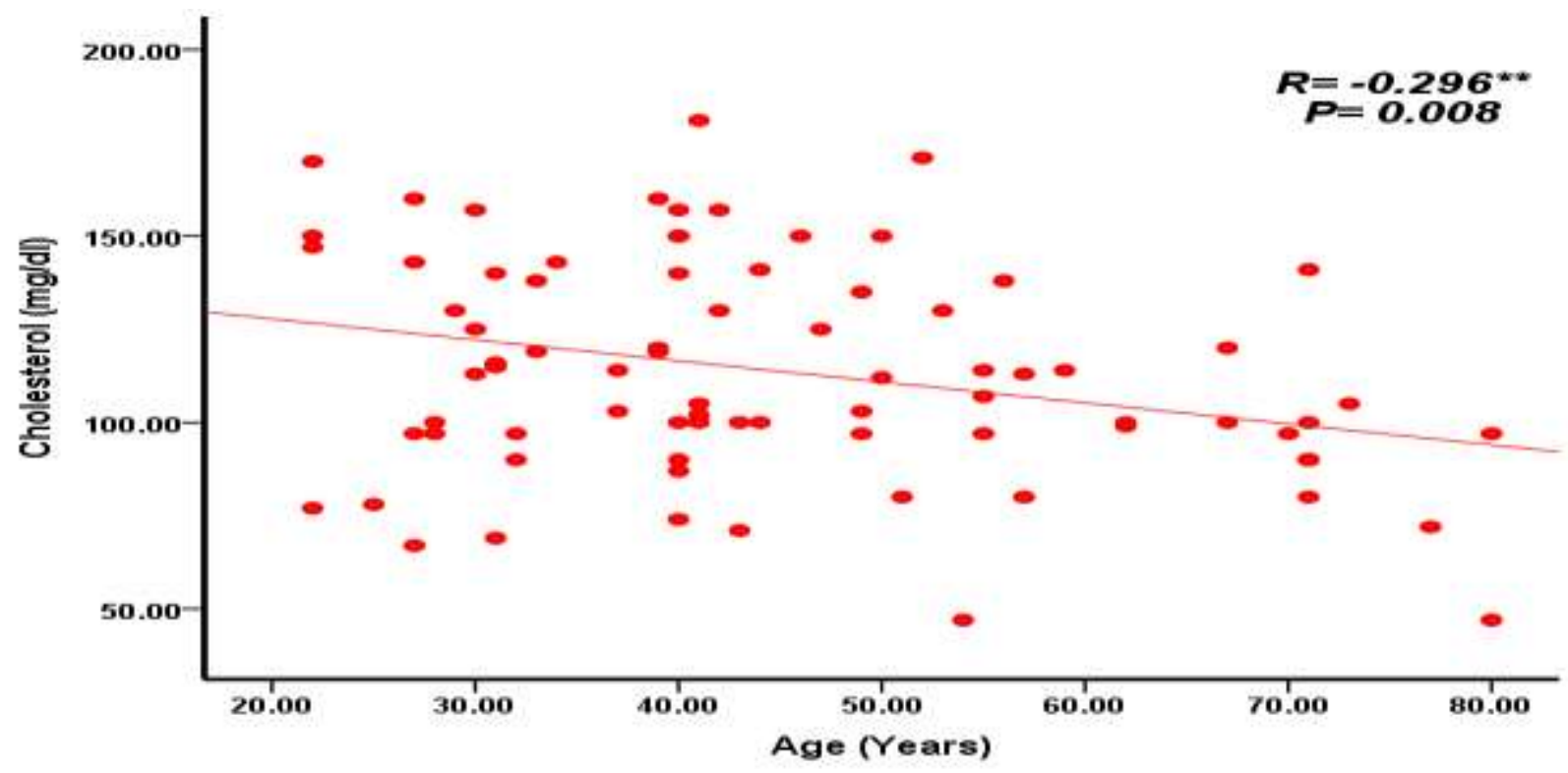

Figure (4):- correlation between cholesterol level and age group in tuberculosis patients:

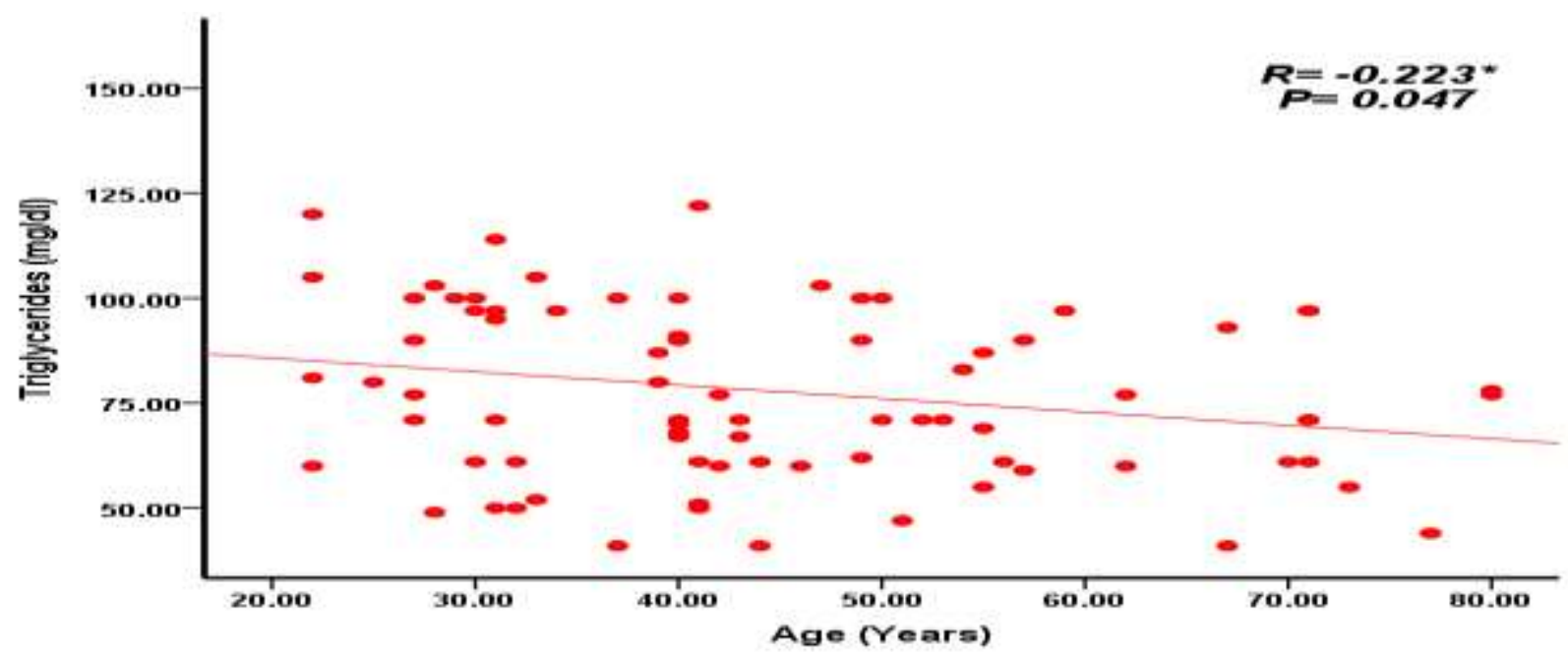

Figure (5):- correlation between TG level and age group in tuberculosis patients:

\section{Discussion:-}

Tuberculosis infection may cause malnutrition through increased metabolic demands and decreased nutrient intake, while nutritional deficiencies may worsen the disease or delay recovery by inhibiting important immune functions. (5)

From the finding of this study it appears that, serum level of protein, albumin, cholesterol and triglyceride were significantly decreased in tuberculosis patients group compared to control group (P. value $=0.000,0.000,0.015$ and 0.000$)$ respectively.

This result agreed with result carried by Yamagishi et al 1999 and Yamanaka et al 2001 which reported that, serum proteins, albumin, cholesterol and triglyceride were significantly lower in tuberculosis patients compared to control group. ${ }^{(9)}(10)$.Also the study in agreement with another study which found significantly decreased in the levels of serum proteins, albumin, cholesterol and triglyceride in tuberculosis patients. ${ }^{(11)}$ Also the result agreed with another result which showed that' in pulmonary tuberculosis biochemical abnormalities such as, low serum albumin level is common and aid in diagnosis. It is well established that changes in levels of serum proteins occur in response to 
both acute and chronic infections. This is especially true immunoglobulins and acute phase proteins. In an infection like tuberculosis, such changes in serum protein levels are expected. ${ }^{(12)}$

Also the present study showed that, there were insignificant different in the levels of serum proteins, albumin, cholesterol and triglyceride in tuberculosis patients according to gender. This result is similar to another result which found, there were insignificant difference in the levels of proteins, albumin, cholesterol and triglyceride between male and female patients. ${ }^{(13)}$

The result of this study showed that, there was significantly decreased in BMI in patients with tuberculoses compared to control group ( $\mathrm{p}$ - value $=0.000$ ). This result agreed with study done in Indonesia and Malawi which showed, low BMI in patients with tuberculoses and this may be due to poor dietary intake, in appetite, anorexia and impaired absorption or increased catabolism . ${ }^{(14)}$ Also the result agreed with another result done by (Hopwell, 1994), which found, low BMI is a known risk factor for mortality. ${ }^{(15)}$ The study showed, there were negative correlation between the levels of serum total proteins, albumin, total cholesterol, triglyceride and ages. $(\mathrm{r}=-0.356$, $\mathrm{p}$, value $=0.001)(\mathrm{r}=-0.273, \mathrm{p}$, value $=0.014)(\mathrm{r}=-0.296, \mathrm{p}$, value $=0.008)(\mathrm{r}=-0.223, \mathrm{p}$, value $=0.047)$ respectively.

\section{References:-}

1. Kumar, V., Abbas, A. K., Richard, N. Robbins Basic Pathology (8th ed.). Saunders Elsevier. 2007: 516-522.

2. Konstantinos, A. «Testing for tuberculosis». Australian Prescriber. 2010; 33:12-18.

3. Danburam, A. Pulmonary tuberculosis in Nigeria. Journal of Infectious Diseases and Immunity.2012;4(2):1619.

4. Modawe,G .Biochemical parameters in tuberculosis in Sudanese Patients .Sudan JMS.2014;3(9):177-180.

5. Sinclair, D., Abba, K., Grobler, L., Sudarsanam, T.D. Nutritional supplements for people being treated for active tuberculosis. Cochrane Database Syst. Rev. 2011;11: 58.

6. Cegielski, J.P., McMurray, D.N. The relationship between malnutrition and tuberculosis: evidence from studies in humans and experimental animals. Int J Tuberc Lung Dis 2004; 8:286-298.

7. Onwubalili, J.K. Malnutrition among tuberculosis patients in Harrow, England. Eur J Clin Nutr 1988; 42: 363 6.

8. Vissers, M.E., Texeira, S.C, Maartens, G. The short term effects of anti-tuberculosis therapy on plasma pyridoxine levels in patients with pulmonary tuberculosis. Int J Tuberk Lung Dis 2004; 8(2): 260-2.

9. Sasaki, Y., Yamagishi, F., Yasi, T., Mizutani, F. A. Case of pulmonary tuberculosis case with pancytopenia accompanied to bone marrow gelatinous transformation. Kekkaku.1999; 74 (4):361-4.

10. Yamanaka, K., Sakai, S., Nomura, F., Akashi, T., Usui, T. A nutritional investigation of homeless patients with tuberculosis. Kekkaku.2001; 76 (4): 363-370.

11. Van Lettow, M., Harries, A.D., Kumwenda, J.J. Micronutrient malnutrition and wasting in adults with pulmonary tuberculosis with and without HIV co-infection in Malawi.BMC Infect Dis. 2004; 4:61.

12. Laxmilkant,C.,Saket Kumar,M.,Raju,M.J. Study of Correlation of Serum Protein Levels with Tuberculosis. International Journal of Recent Trends in Science and Technology. 2016 ; 20 (2):248-251.

13. Harries, A.D., Nkhoma, W.A., Thompson. P.J., Nyangulu, D.S., Wirima, J.J. Nutritional status in Malawian patients with pulmonary tuberculosis and response to chemotherapy. Eur J Clin Nutr 1988; 42:445-450.

14. Balley,L., Fawzi, W ., Semba,R. The role of malnutrition in tuberculosis and Human Immunodeficiency.2003 ;61(3): 163-171.

15. Jemikalajah,, J.D., Okogun, G.R.A., Adu, M.E., Okolie, G.C. EVALUATION OF SERUM PROTEINS IN PULMONARY TUBERCULOSIS African Journal of Cellular Pathology.2014; 3: 20-24. Hopwell,P., Farer,L ., Bass,J. Treatment of tuberculosis and tuberculosis infection in adults and children. American Thorocic Society and the Centers for Disease. 1994; 149:1359-1374. 